\title{
Tris-diamine-derived transition metal complexes of flurbiprofen as cholinesterase inhibitors
}

\author{
Muhammad Jamil, Nargis Sultana, Rizwan Ashraf, Muhammad Sarfraz, \\ Muhammad llyas Tariq*, Muhammad Mustaqeem \\ Department of Chemistry, University of Sargodha, Sargodha 40100, Pakistan
}

*For correspondence: Email: tariqmi@uos.edu.pk, tariqmi2000@yahoo.com

\begin{abstract}
Purpose: To synthesize novel tris-diamine-derived transition metal complexes of flurbiprofen $M\left(C_{2} H_{8} N_{2}\right)_{3}$ (fp) $)_{2}$ and $M\left(C_{3} H_{10} N_{2}\right)_{3}(f p)_{2}$, and to evaluate their acetylcholinesterase (AChE) and butyrylcholinesterase (BChE) inhibitory activities.

Method: Tris-diamine-derived transition metal complexes of $\mathrm{Co}(\mathrm{II}), \mathrm{Ni}(\mathrm{II})$, and $\mathrm{Mn}(\mathrm{II})$ were synthesized and characterized using ultraviolet-visible (UV-Vis) spectroscopy, Fourier transform-infrared (FT-IR) spectroscopy, elemental analysis, magnetic susceptibility, conductivity measurement and single crystal $x$-ray analysis. The synthesized complexes were also evaluated for their AChE and BChE inhibitory activities.

Results: Based on magnetic susceptibility and electronic studies, the synthesized complexes possessed distorted octahedral geometry. Conductance measurements indicated that diamine-derived metal complexes of flurbiprofen were electrolytes, whereas, simple metal complexes of flurbiprofen were non-electrolytes. The structure of $\mathrm{Ni}\left(\mathrm{C}_{2} \mathrm{H}_{8} \mathrm{~N}_{2}\right)_{3}(\mathrm{fp})_{2}$ was also confirmed by single crystal x-ray analysis. The synthesized metal complexes exhibited moderate-to-very good inhibition of AChE and $B C h E$. In vitro assays revealed that $\mathrm{Ni}$ complexes were most active, with the least half-maximal inhibitory concentration (IC $\mathrm{C}_{50}$ ) values against $A C h E$ and $B C h E$, compared to Co and Mn complexes. Furthermore, 1, 2-diaminoethane-derived complexes were more potent, with lower $I C_{50}$ values against both AChE and BChE, compared to 1,3-diaminopropane-derived complexes. Among the complexes, 4a and 5 a revealed significant cholinesterase inhibitory activities relative to the standard drug, galantamine. Conclusion: All the synthesized metal complexes are active against AChE and BChE, but only $4 a$ and $5 \mathbf{a}$ are more active than the standard drug, galantamine, indicating their potential for drug development.
\end{abstract}

Keywords: Flurbiprofen, Cholinesterase, Diamines, Galantamine, Metal complexes, Cholinesterase inhibition

\begin{abstract}
This is an Open Access article that uses a funding model which does not charge readers or their institutions for access and distributed under the terms of the Creative Commons Attribution License (http://creativecommons.org/licenses/by/4.0) and the Budapest Open Access Initiative (http://www.budapestopenaccessinitiative.org/read), which permit unrestricted use, distribution, and reproduction in any medium, provided the original work is properly credited.

Tropical Journal of Pharmaceutical Research is indexed by Science Citation Index (SciSearch), Scopus, International Pharmaceutical Abstract, Chemical Abstracts, Embase, Index Copernicus, EBSCO, African Index Medicus, JournalSeek, Journal Citation Reports/Science Edition, Directory of Open Access Journals (DOAJ), African Journal Online, Bioline International, Open-J-Gate and Pharmacy Abstracts
\end{abstract}

\section{INTRODUCTION}

It has been estimated that worldwide, 35 million people suffer from Alzheimer Disease (AD), and that this number is expected to quadruple in the next 50 years [1,2]. The likely cause of this 
disease is accumulation of heavy metals in the brain, oxidative stress, aging as well as variation in the level of cholinesterases.

The primary pharmacological strategies for the control of $A D$ involve enhancement of cholinergic neurotransmission by reducing the rate of decomposition of acetylcholine (ACh) at synapses through the use of acetylcholinesterase inhibitors (AChEls) [3,4]. Tetrahydroacridine and its derivatives are acclaimed as the first synthetic AChEls, whereas Ladostigil which possesses neuro-protective cholinesterase inhibitory properties, was developed for AD [5,6]. Recently, Galantamine, Rivastigmine and Donepezil were recommended for inhibiting the activity of cholinesterases for the maintenance and control of neural dysfunctions associated with AD [7-9].

Derivatives of NSAID-AChEI have recently been prepared to target neuro-inflammation and vesicant-induced inflammation [10]. This was based on their effectiveness against inflammatory disorders through inhibition of cyclooxygenase and activation of the cholinergic anti-inflammatory pathway [11]. Some metal chelates of glycine, ethylene-diamine, 1, 3diaminopropane and tetramethylethylenediamine have been reported as cholinesterase inhibitors $[12,13]$. The AChEls are associated with side effects such as diarrhea, nausea, anorexia, fatigue, rhinitis, asthenia, leg cramps, insomnia, dizziness, and vomiting. However, pharmacological evaluation of synthesized drugs, docking and in vivo studies could provide better alternative drugs for cholinesterase inhibition $[14,15]$.

In the present study which is a continuation of the search for new potent cholinesterase inhibitors [16], and keeping in view the cholinesterase inhibitory properties of NSAIDsdiamines, a relatively new class of flurbiprofen and its transition metal complexes with diamines (1,2-diaminoethane and 1,3-diaminopropane) was introduced as anti-cholinesterase inhibitors.

\section{EXPERIMENTAL}

\section{Materials}

Analytical grade chemicals and reagents including metal salts (nickel acetate, cobalt acetate, manganese acetate), ethylene-diamine (1, 2-diaminoethane), propane-diamine (1, 3diaminopropane) and solvents purchased from Merck Millipore, England were used as received. Flurbiprofen acid was purchased from Sigma Aldrich, England. The progress of the reactions was monitored by using TLC plates. Shimadzu (FT)-IR-8400S spectrophotometer was used for recording infrared spectra in the region 4000 $400 \mathrm{~cm}^{-1}$ with $\mathrm{KBr}$ disc, while Jenway 6505 UV/Visible double beam spectrophotometer was employed for UV-visible spectra. Micro analytical data $(\mathrm{C}, \mathrm{H}, \mathrm{N}, \%)$ were obtained using Elemental Analyzer (Perkin Elmer, USA). Molar conductance of the complexes at $25{ }^{\circ} \mathrm{C}$ was measured with Inolab Conductivity Bridge 720 . Magnetic susceptibility was calculated with Stanton SM12/S Gouy's balance calibrated using $\mathrm{Hg}\left[\mathrm{Co}(\mathrm{NCS})_{4}\right]$.

\section{General procedure for the synthesis of metal flurbiprofen complexes (3a-3c)}

Flurbiprofen acid 1 (2.44 g, 0.01 mole) was dissolved in $20 \mathrm{ml}$ de-ionized water by adding $\mathrm{KOH}$ (0.56 g, 0.01 mole) until the solution became clear, forming potassium salt of flurbiprofen. To this solution, aqueous solutions of metal acetate salts ( $\mathrm{Ni}$, Co and $\mathrm{Mn}$ acetates, 0.005 mole) were added drop-wise with constant stirring in a round bottom flask, and stirring was continued for further $15 \mathrm{~min}$ at $40{ }^{\circ} \mathrm{C}$. The precipitates of flurbiprofen metal complexes (3a3c) formed were filtered, washed with ethanol and distilled water, and dried at room temperature.

\section{Synthesis of tris (1, 2-diaminoethane) metal flurbiprofen complexes (4a-4c)}

To each stirred suspension of synthesized flurbiprofen metal complexes (3a-3c) in ethanol/water (1:1 v:v) solution, $2.0 \mathrm{ml}$ of $1,2-$ diaminoethane (0.03 mole) was added. The reaction mixtures were stirred for 15-20 min at room temperature until they became clear with characteristic colors. Slow evaporation of these solutions produced the desired solid products tris (1, 2-diaminopropane)-flurbiprofen metal complexes (4a-4c).

Synthesis of tris (1, 3-diaminopropane) metal flurbiprofen complexes (5a-5c)

To each stirred suspension of synthesized flurbiprofen metal complexes (3a-3c) in ethanol/water (1:1, v:v) solution, $1.68 \mathrm{ml}$ of 1,3diaminopropane (0.02 mole) was added, and reaction mixtures were stirred for $15-20 \mathrm{~min}$ at room temperature until they became clear with characteristic colors of the metal complexes. Slow evaporation of these solutions produced the desired solid tris (1,3-diaminopropane)flurbiprofen metal complexes (5a-5c). 


\section{Single crystal $\mathrm{x}$-ray analysis}

For compound $\mathrm{Ni}\left(\mathrm{C}_{2} \mathrm{H}_{8} \mathrm{~N}_{2}\right)_{3}(\mathrm{fp})_{2}(4 \mathrm{a})$, x-ray measurements were calculated on a Bruker kappa APEXII (CCD) diffractometer equipped with a graphite-mono-chromated Mo-Ka $(\lambda \ldots 0.71073 \AA)$ radiation. For data collection multi-scan, absorption correction and $v$ scans were applied. The structure of $\mathbf{4 a}$ was resolved by using SHELXS-97. Geometrical considerations were made for hydrogen atoms and methyl groups defined as rigid groups which could rotate freely. Final structural refinement on $\mathrm{F}^{2}$ was carried out by least-squares, full-matrix techniques using SHELXL-97 $[17,18]$. ORTEP diagram of the molecule was obtained by using Mercury software of Cambridge Crystallographic Resources.

\section{Determination of AChE and BChE inhibitory activities}

Standard colorimetric procedures were used in assaying the inhibitory activities of the complexes $[16,19]$. Acetylthiocholine iodide, butyrylthiocholine iodide, AChE, BChE and DTNB (Sigma-Aldrich) were used. The concentration of each coloured reaction product was measured at $412 \mathrm{~nm}$ in a $\mu$ Quant microplate spectrophotometer (MQX200). Galantamine hydrobromide from Lycoris Sp. (Sigma-Aldrich) and Donepezil were used as reference drugs.
Stock solutions of the synthesized metal complexes were prepared in $0.1 \mathrm{M}$ phosphate buffer, pH 8. Controlled amount of DTNB (Ellman's reagent), metal complex and AChE or BChE $(0.03 \mathrm{U} / \mathrm{ml})$ were prepared and allowed to react by pre-incubating at $30{ }^{\circ} \mathrm{C}$ for $10 \mathrm{~min}$. Thereafter, $1 \mathrm{mM} \mathrm{ATCl}$ or BTCl was added, and the reaction mixture was incubated further for 15 min. Absorbance was read thrice at $412 \mathrm{~nm}$, and $I_{50}$ values of the compounds were calculated by plotting sample concentration against inhibition.

\section{RESULTS}

All the synthesized metal complexes exhibited good-to-excellent yields. The purity of the complexes was measured through sharp melting point (m.pt.) determination. The synthesized metal complexes were characterized using single FT-IR, UV-VIS spectroscopy, conductivity measurements, elemental analysis, magnetic susceptibility and single crystal X-ray analysis. Distorted octahedral geometry was proposed for all the metal complexes based on magnetic susceptibility and electronic spectra. High value of conductance for diamine-derived metal complexes confirmed their ionic nature. Physical data and elemental (CHNS/M) analysis of the synthesized complexes were consistent with the proposed structures. The scheme of the synthesis is shown in Figure 1.<smiles>CC(C(=O)O)c1ccc(-c2ccccc2)c(F)c1</smiles>

1<smiles>CC(=O)OC(=O)C(C)c1ccc(-c2ccccc2)c(F)c1</smiles>

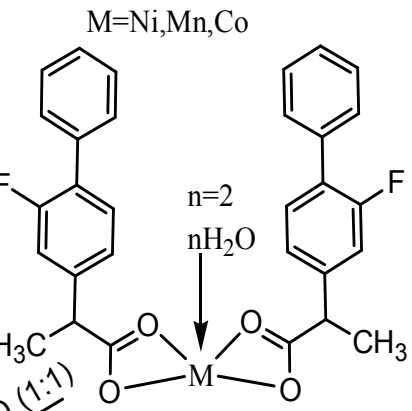

3a-c
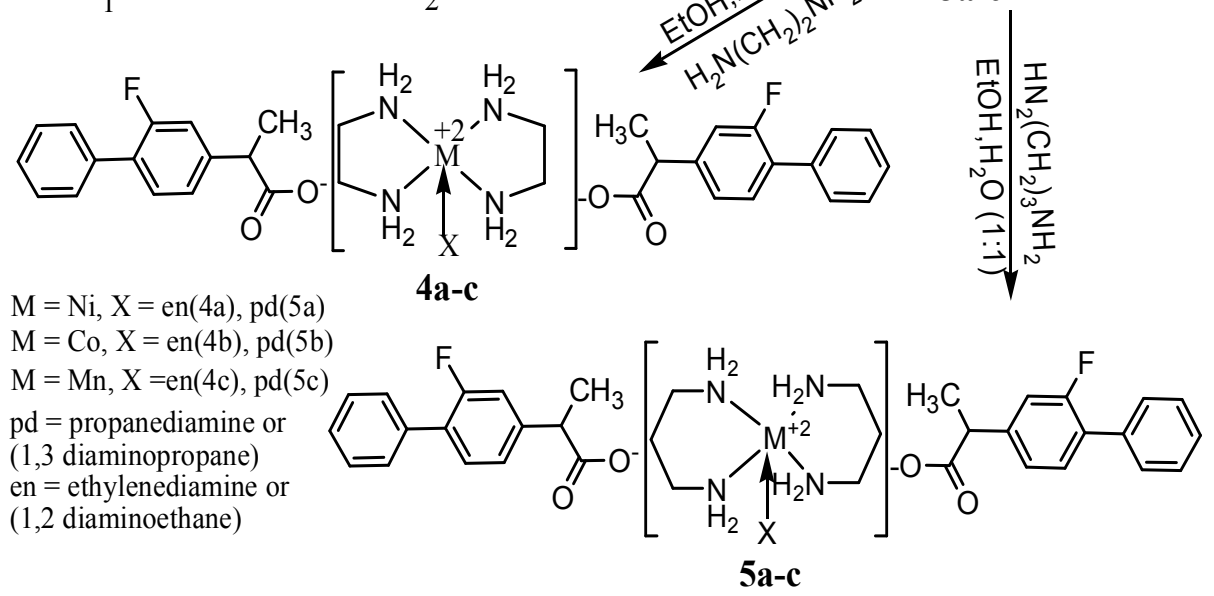

Figure 1: Scheme for the synthesis of tris-diamine-derived metal flurbiprofen complexe 


\section{$\mathrm{Ni}\left(\mathrm{H}_{2} \mathrm{O}\right)_{2}(\mathrm{fp})_{2}(3 \mathrm{a})$}

Light green solid, yield $=83 \%$, m.pt. $=165-167^{\circ} \mathrm{C}$; analytically calculated values for $\mathrm{C}_{30} \mathrm{H}_{28} \mathrm{~F}_{2} \mathrm{O}_{6} \mathrm{Ni}$ (\%): $\mathrm{C}=61.99, \mathrm{H}=4.86$; found: $\mathrm{C}=61.89, \mathrm{H}=$ 4.90; selected FT-IR data $\left(\mathrm{KBr}, \mathrm{cm}^{-1}\right): \bar{U}\left(M \leftarrow \mathrm{H}_{2} \mathrm{O}\right)$ $=3683 \mathrm{~cm}^{-1}, \bar{U}(M \leftarrow O)=468 \mathrm{~cm}^{-1}, \bar{U}(\mathrm{COO})$ $1667 \mathrm{~cm}^{-1} \bar{U} \quad(\mathrm{C}-\mathrm{H})=2794 \mathrm{~cm}^{-1}$ and disappearance of broad $\bar{u}(\mathrm{O}-\mathrm{H})$ peak of $(\mathrm{COOH})$ at $3200-3400 ; \quad \lambda_{\max }\left(\mathrm{cm}^{-1}\right)=12713,18274$, 27237; $\left.\Omega^{-1} \mathrm{~cm}^{2} \mathrm{~mol}^{-1}\right)=31, \mu$ eff $=3.1$

\section{$\mathrm{Co}\left(\mathrm{H}_{2} \mathrm{O}\right)_{2}(f p)_{2}(3 b)$}

Light pink solid, yield $=71 \%$, m.pt. $=153-155^{\circ} \mathrm{C}$; analytically calculated values for $\mathrm{C}_{30} \mathrm{H}_{28} \mathrm{~F}_{2} \mathrm{O}_{6} \mathrm{Co}$ (\%): $\mathrm{C}=61.97, \mathrm{H}=4.85$; found: $\mathrm{C}=61.95, \mathrm{H}=$ 4.84; selected FT-IR data $\left(\mathrm{KBr}, \mathrm{cm}^{-1}\right): \quad \bar{u}$ $\left(\mathrm{M} \leftarrow \mathrm{H}_{2} \mathrm{O}\right) 3620 \mathrm{~cm}^{-1}, \bar{u}(M \leftarrow O) 478 \mathrm{~cm}^{-1}, \bar{u}(\mathrm{COO})$ $1673 \mathrm{~cm}^{-1} \bar{U}(\mathrm{C}-\mathrm{H})=2824 \mathrm{~cm}^{-1}$ and disappearance of broad $\bar{u}(\mathrm{O}-\mathrm{H})$ peak of $(\mathrm{COOH})$ at $3200-3400$, $\lambda_{\max }\left(\mathrm{cm}^{-1}\right)=14467,21332,17384-17565 ; \Omega^{-}$ $\left.{ }^{1} \mathrm{~cm}^{2} \mathrm{~mol}^{-1}\right)=29, \mu$ eff $=1.8$

\section{$M n\left(H_{2} \mathrm{O}\right)_{2}(f p)_{2}(3 c)$}

White solid, yield $=87 \%$, m.pt. $=150-152^{\circ} \mathrm{C}$; analytically calculated values for $\mathrm{C}_{30} \mathrm{H}_{28} \mathrm{~F}_{2} \mathrm{O}_{6} \mathrm{Mn}$ (\%): $\mathrm{C}=62.40, \mathrm{H}=4.89$; found: $\mathrm{C}=62.32, \mathrm{H}=$ 4.88; selected FT-IR data $\left(\mathrm{KBr}, \mathrm{cm}^{-1}\right): \bar{U}$ $\left(\mathrm{M \leftarrow H_{2 } \mathrm { O } )} 3655 \mathrm{~cm}^{-1}, \bar{U}(\mathrm{M} \leftarrow \mathrm{O}) 443 \mathrm{~cm}^{-1}, \bar{U}\right.$ (COO) $1682 \mathrm{~cm}^{-1} \bar{U}(\mathrm{C}-\mathrm{H}) \quad 2817 \mathrm{~cm}^{-1}$ and disappearance of broad $\bar{U}(\mathrm{O}-\mathrm{H})$ peak of $(\mathrm{COOH})$ at $3200-3400, \lambda_{\max }\left(\mathrm{cm}^{-1}\right)=16645,20755$, 24532, 27234; $\left.\Omega^{-1} \mathrm{~cm}^{2} \mathrm{~mol}^{-1}\right)=26, \mu$ eff $=1.9$

\section{$\mathrm{Ni}\left(\mathrm{C}_{2} \mathrm{H}_{8} \mathrm{~N}_{2}\right)_{3}(\mathrm{fp})_{2}(4 \mathrm{a})$}

Violet crystals, yield $=78 \%$, m.pt. $=82-284^{\circ} \mathrm{C}$ ); analytically calculated values for $\mathrm{C}_{36} \mathrm{H}_{50} \mathrm{~F}_{2} \mathrm{~N}_{6} \mathrm{O}_{4} \mathrm{Ni}$ (\%): $\mathrm{C}=59.43, \mathrm{H}=6.93, \mathrm{~N}=11.55$; found: $\mathrm{C}=$ 59.35, $\mathrm{H}=6.94, \mathrm{~N}=11.54$; selected FT-IR data $\left(\mathrm{KBr}, \mathrm{cm}^{-1}\right): \bar{U} \quad(M \leftarrow N)=501 \mathrm{~cm}^{-1}, \bar{U}(\mathrm{CH})$ $=2841 \mathrm{~cm}^{-1}$; disappearance of broad $\bar{U}(\mathrm{O}-\mathrm{H})$ peak of $(\mathrm{COOH})$ at $3200-3400 \mathrm{~cm}^{-1}$ region, and disappearance of $\bar{U}(M \leftarrow O)$ peak at $440-490 \mathrm{~cm}^{-1}$ region,; $\lambda_{\max }\left(\mathrm{cm}^{-1}\right)=18532,22247,29408 ; \Omega^{-}$ $\left.{ }^{1} \mathrm{~cm}^{2} \mathrm{~mol}^{-1}\right)=186, \mu$ eff $=3.3$

\section{Co $\left(\mathrm{C}_{2} \mathrm{H}_{8} \mathrm{~N}_{2}\right)_{3}(\mathrm{fp})_{2}(4 \mathrm{~b})$}

Greenish-brown solid, yield $=80 \%$, m.pt. $=273-$ $275^{\circ} \mathrm{C}$; analytically calculated values for $\mathrm{C}_{36} \mathrm{H}_{50} \mathrm{~F}_{2} \mathrm{~N}_{6} \mathrm{O}_{4} \mathrm{Co}(\%): \mathrm{C}=59.41 ; \mathrm{H}=6.93 ; \mathrm{N}=$ 11.55; found: $\mathrm{C}=59.38 ; \mathrm{H}=6.97 ; \mathrm{N}=11.52$; selected FT-IR data $\left(\mathrm{KBr}, \mathrm{cm}^{-1}\right): \bar{U}(M \leftarrow N)=569$ $\mathrm{cm}^{-1} ; \bar{U}(\mathrm{CH})=2819 \mathrm{~cm}^{-1}$; disappearance of $\bar{U}$ $(M \leftarrow O)$ peak at $440-490 \mathrm{~cm}^{-1}$ region and broad $\bar{U}(\mathrm{O}-\mathrm{H})$ peak of $(\mathrm{COOH})$ at $3200-3400 \mathrm{~cm}^{-1}$ region; $\lambda_{\max }\left(\mathrm{cm}^{-1}\right)=14797,19456,21447-$ 21673; $\left.\Omega^{-1} \mathrm{~cm}^{2} \mathrm{~mol}^{-1}\right)=174, \mu$ eff $=1.8$

\section{$\operatorname{Mn}\left(\mathrm{C}_{2} \mathrm{H}_{12} \mathrm{~N}_{2}\right)_{3}(\mathrm{fp})_{2}(4 \mathrm{c})$}

Dark brown solid, yield $=77 \%$, m.pt. $=266$ $268^{\circ} \mathrm{C}$;; analytically calculated values for $\mathrm{C}_{36} \mathrm{H}_{50} \mathrm{~F}_{2} \mathrm{~N}_{6} \mathrm{O}_{4} \mathrm{Mn}$ (\%): $\mathrm{C}=59.74, \mathrm{H}=6.96, \mathrm{~N}$ =11.61; found: $\mathrm{C}=59.69, \mathrm{H}=6.97, \mathrm{~N}=11.63$; selected FT-IR data $\left(\mathrm{KBr}, \mathrm{cm}^{-1}\right): \bar{U}(M \leftarrow N)=530$ $\mathrm{cm}^{-1}, \bar{U}(\mathrm{CH})=2878 \mathrm{~cm}^{-1}$; disappearance of broad $\bar{U}(\mathrm{O}-\mathrm{H})$ peak of $\bar{U}(\mathrm{COOH})$ at $3200-3400$ region and $\bar{U}(M \leftarrow O)$ peak in $440-490 \mathrm{~cm}^{-1}, \lambda_{\max }\left(\mathrm{cm}^{-1}\right)=$ 18354, 20862, 25568, 29421; $\left.\Omega^{-1} \mathrm{~cm}^{2} \mathrm{~mol}^{-1}\right)=$ $163, \mu$ eff $=2.1$

\section{$\mathrm{Ni}\left(\mathrm{C}_{3} \mathrm{H}_{10} \mathrm{~N}_{2}\right)_{3}(\mathrm{fp})_{2}(5 \mathrm{a})$}

Violet crystals, yield $=85 \%$, m.pt. $=272-274^{\circ} \mathrm{C}$ ), analytically calculated values for $\mathrm{C}_{39} \mathrm{H}_{54} \mathrm{~F}_{2} \mathrm{~N}_{6} \mathrm{O}_{4} \mathrm{Ni}$ (\%): $\mathrm{C}=61.03 ; \mathrm{H}=7.09, \mathrm{~N}=10.95$; found: $\mathrm{C}=$ $60.90, \mathrm{H}=7.03, \mathrm{~N}=11.03$; selected $\mathrm{FT}-\mathrm{IR}$ data $\left(\mathrm{KBr}, \mathrm{cm}^{-1}\right): \bar{U}(M \leftarrow N)=501 \mathrm{~cm}^{-1}, \bar{U}(\mathrm{CH})=2834$ $\mathrm{cm}^{-1}$ and disappearance of $\bar{U}\left(M \leftarrow H_{2} \mathrm{O}\right), \bar{U}$ $(M \leftarrow O)$ at $440-490 \mathrm{~cm}^{-1}$ and broad $\bar{U}(\mathrm{O}-\mathrm{H})$ peak at $3200-3400 \mathrm{~cm}^{-1}, \lambda_{\max }\left(\mathrm{cm}^{-1}\right)=18521,22234$, 29397, $\left.\Omega^{-1} \mathrm{~cm}^{2} \mathrm{~mol}^{1}\right)=175, \mu$ eff $=3.3$.

\section{$\mathrm{Co}\left(\mathrm{C}_{3} \mathrm{H}_{10} \mathrm{~N}_{2}\right)_{3}(\mathrm{fp})_{2}(\mathrm{sb})$}

Greenish-brown solid, yield $=75 \%$, m.pt. $=265-$ $267^{\circ} \mathrm{C}$ ), analytically calculated values for $\mathrm{C}_{39} \mathrm{H}_{54} \mathrm{~F}_{2} \mathrm{~N}_{6} \mathrm{O}_{4} \mathrm{Co}(\%): \mathrm{C}=61.01, \mathrm{H}=7.09, \mathrm{~N}=$ 10.95; found: $\mathrm{C}=60.11, \quad \mathrm{H}=7.00, \mathrm{~N}=10.91$; selected FT-IR data $\left(\mathrm{KBr}, \mathrm{cm}^{-1}\right): \bar{U}(M \leftarrow N)=569$ $\mathrm{cm}^{-1}, \bar{U}(\mathrm{CH})=2861 \mathrm{~cm}^{-1}$ and disappearance of $\bar{U}$ $(\mathrm{M} \leftarrow \mathrm{O}), \bar{U}\left(\mathrm{M} \leftarrow \mathrm{H}_{2} \mathrm{O}\right)=$ peaks and broad $\bar{U}(\mathrm{O}-\mathrm{H})$ peak at $3200-3400 \mathrm{~cm}^{-1}$ region, $\lambda_{\max }\left(\mathrm{cm}^{-1}\right)=$ 14782, 19435, 21427-21616; $\left.\Omega^{-1} \mathrm{~cm}^{2} \mathrm{~mol}^{-1}\right)=169$, $\mu$ eff $=1.8$

\section{$\operatorname{Mn}\left(C_{3} H_{12} N_{2}\right)_{3}(f p)_{2}(3 c)$}

Dark brown compound, yield $=73 \%$; analytically calculated values for $\mathrm{C}_{39} \mathrm{H}_{54} \mathrm{~F}_{2} \mathrm{~N}_{6} \mathrm{O}_{4} \mathrm{Mn}$ (\%): $\mathrm{C}=$ 61.33, $\mathrm{H}=7.13, \mathrm{~N}=11.00$; found: $\mathrm{C}=61.26 ; \mathrm{H}$ $=7.08, \mathrm{~N}=11.30$; selected FT-IR data $\left(\mathrm{KBr}, \mathrm{cm}^{-}\right.$ $\left.{ }^{1}\right): \bar{U}(M \leftarrow N)=530 \mathrm{~cm}^{-1}, \bar{U}(\mathrm{CH})=2863 \mathrm{~cm}^{-1}$ and disappearance of $\bar{U}(M \leftarrow O)$ and $\bar{U}\left(M \leftarrow \mathrm{H}_{2} \mathrm{O}\right)$ peaks, and broad $\bar{U}(\mathrm{O}-\mathrm{H})$ peak at $3200-3400$ $\mathrm{cm}^{-1}$ region; $\lambda_{\max }\left(\mathrm{cm}^{-1}\right)=18366,20887,25589$, 29438; $\left.\Omega^{-1} \mathrm{~cm}^{2} \mathrm{~mol}^{-1}\right)=153 ; \mu$ eff $=2.1$

\section{X-ray crystallography}

After refinement, the crystal data of the compound $\mathrm{Ni}\left(\mathrm{C}_{2} \mathrm{H}_{8} \mathrm{~N}_{2}\right)_{3} \quad(f p)_{2} \quad$ (4a) showed formation of a complex consisting of 2 types of ionic moieties (Figure 2, Table 1). 


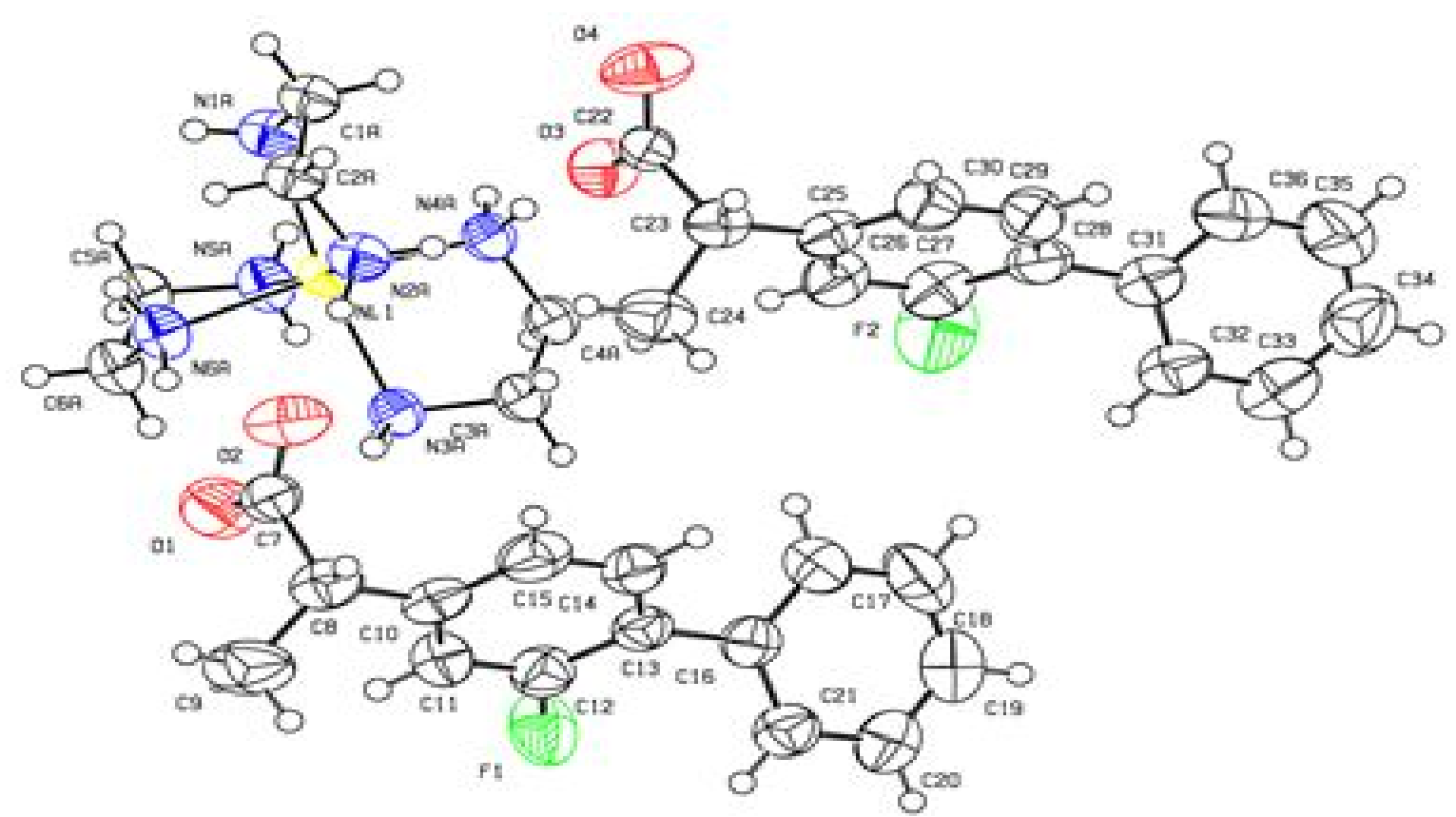

Figure 2: ORTEP diagram of $\mathrm{Ni}\left(\mathrm{C}_{2} \mathrm{H}_{8} \mathrm{~N}_{2}\right)_{3}(f p)_{2}(4 \mathrm{a})(\mathrm{CCDC} \# 1569831)$

Table 1: Crystal data and structure refinement for (4a)

\begin{tabular}{|c|c|}
\hline Parameter & Data \\
\hline Identification code & Shelx \\
\hline Empirical formula & $\mathrm{C} 36 \mathrm{H} 50 \mathrm{~F} 2 \mathrm{~N} 6 \mathrm{Ni} \mathrm{O} 4$ \\
\hline Formula weight & 725.4943 \\
\hline Temperature & 296(2) K \\
\hline Wavelength & $0.71073 \mathrm{~A}$ \\
\hline Crystal system & Triclinic \\
\hline Space group & $P-1$ \\
\hline \multicolumn{2}{|l|}{ Unit cell dimensions } \\
\hline$a=9.2344(8) A$ & $\alpha=88.754(3)^{\circ}$ \\
\hline $\mathrm{b}=11.9541(10) \mathrm{A}$ & $\beta=82.042(3)^{\circ}$ \\
\hline$c=17.6358(15) A$ & $\mathrm{y}=86.611(3)^{\circ}$ \\
\hline Volume & $1924.5(3) A^{3}$ \\
\hline Z & 2 \\
\hline Density (calculated) & $1.172 \mathrm{mg} / \mathrm{m}^{3}$ \\
\hline Absorption coefficient & $0.559 \mathrm{~mm}^{-1}$ \\
\hline $\mathrm{F}(000)$ & 712 \\
\hline Crystal size & $0.380 \times 0.280 \times 0.200 \mathrm{~mm}^{3}$ \\
\hline $\begin{array}{l}\text { Theta range for data } \\
\text { collection }\end{array}$ & 2.054 to $26.998^{\circ}$ \\
\hline Index ranges & $\begin{array}{l}-10<=\mathrm{h}<=11,-15<=\mathrm{k}<=15 \\
-22<=\mid<=22\end{array}$ \\
\hline Reflections collected & 28586 \\
\hline Independent reflections & $8273[R($ int $)=0.0377]$ \\
\hline $\begin{array}{l}\text { Completeness to theta } \\
=25.242^{\circ}\end{array}$ & $99.2 \%$ \\
\hline Refinement method & $\begin{array}{l}\text { Full-matrix least-squares } \\
\text { on } \mathrm{F}^{2}\end{array}$ \\
\hline $\begin{array}{l}\text { Data / restrains / } \\
\text { parameters }\end{array}$ & $8273 / 0 / 469$ \\
\hline Goodness-of-fit on $\mathrm{F}^{2}$ & 1.040 \\
\hline Final $R$ indices & $\mathrm{R} 1=0.0788, w \mathrm{R} 2=$ \\
\hline [1>2sigma(1) & 0.2356 \\
\hline $\mathrm{R}$ indices (aa data) & $\begin{array}{l}\mathrm{R} 1=0.1027, w R 2= \\
0.2581\end{array}$ \\
\hline Extinction coefficient & $\mathrm{n} / \mathrm{a}$ \\
\hline $\begin{array}{l}\text { Largest diff. peak and } \\
\text { hole }\end{array}$ & 1.705 and -0.637 e. $A^{-3}$ \\
\hline
\end{tabular}

The co-ordination sphere around nickel cation was octahedral with basal plane A (N1/N2/N3/N4/N5/N6) of six nitrogen atoms from three molecules of ethylene-diamines (1,2diaminoethane). The structure contained two independent flurbiprofen anions and central tris (ethylene-diamine) nickel cation in the crystal structure. The structure was stabilised by intermolecular and intramolecular hydrogen bonds $(\mathrm{N}-\mathrm{H} . . . \mathrm{O})$ (Figure 3$)$.

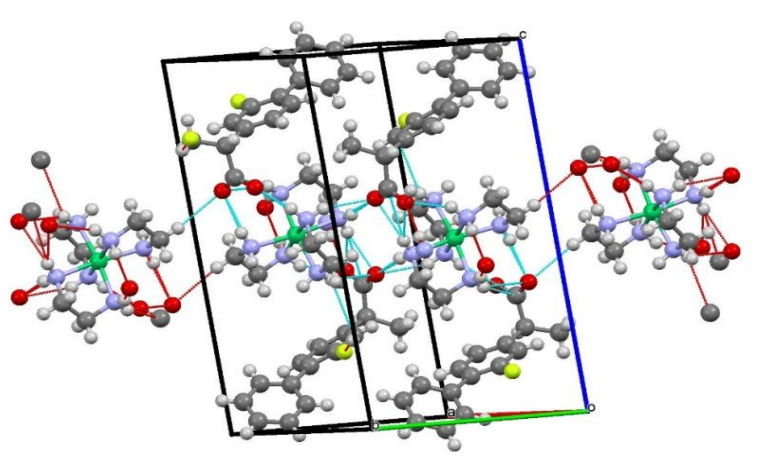

Figure 3: Packing diagram of 4 a showing $\mathrm{H}$-bonding

\section{Spectral data}

The FT-IR analysis of the compounds was in agreement with relevant literature on complex formation. Discussion was focused on the important peaks. Appearance of bands in the range $1547-1692 \mathrm{~cm}^{-1}$ is usually attributed to $\mathrm{OH}$ belonging to the $-\mathrm{COOH}$ functional group, while IR peaks which appear in the range of $1419-1487 \mathrm{~cm}^{-1}$ belong to aromatic $=\mathrm{CH}$ - group. The bands within $451-462 \mathrm{~cm}^{-1}$ range are 
assigned to metal-oxygen bonds ( $\mathrm{M} \leftarrow \mathrm{O})$, while bands within the range 507 to $594 \mathrm{~cm}^{-1}$ are attributed to the $\bar{U}(M \leftarrow N)$ metal-nitrogen bonds. IR analyses of the complexes revealed that $\bar{U}$ $(M \leftarrow N)$ metal nitrogen peaks were not observed for 3a-3c which were synthesized from transition metals and ligands only. However, when 1, 2diaminoethane and 1, 3-diaminopropane were added to 3a-3c complexes to form $4 a-4 c$ and 5a-5c, the $\bar{U}(M \leftarrow N)$ metal nitrogen peaks appeared in the range of $507-594 \mathrm{~cm}^{-1}$, which confirmed chelation between metal and the nitrogen atoms of 1, 2-diaminoethane and 1, 3diaminopropane. Furthermore, $\bar{U}\left(\mathrm{M} \leftarrow \mathrm{H}_{2} \mathrm{O}\right)$ and $\bar{U}$ $(M \leftarrow O)$ peaks disappeared in these complexes.

\section{UV/Vis spectra and magnetic susceptibility}

The electronic spectra of 3D-transition metal complexes were recorded in $10^{-3}$ to $10^{-5} \mathrm{M}$ solutions of each metal complex in DMSO, in a wavelength range of $200-800 \mathrm{~nm}$. The electronic spectra of $\mathrm{Ni}(\mathrm{II})$ complexes showed that $\mathbf{3 a}$ had three absorption peaks at 12713, 18274 and $27237 \mathrm{~cm}^{-1}$; $4 \mathrm{a}$ had three absorption peaks at 18532, 22247 and $29408 \mathrm{~cm}^{-1}$, while 5a produced three absorption peaks at 18521, 22234 and $29397 \mathrm{~cm}^{-1}$. These peaks were expected due to ${ }^{3} \mathrm{~A}_{2 g}(\mathrm{~F}) \rightarrow{ }^{3} \mathrm{~T}_{2 g}(\mathrm{~F}),{ }^{3} \mathrm{~A}_{2 g}(\mathrm{~F})$ $\rightarrow{ }^{3} \mathrm{~T}_{1 \mathrm{~g}}(\mathrm{~F})$ and ${ }^{3} \mathrm{~A}_{2 \mathrm{~g}}(\mathrm{~F}) \rightarrow{ }^{3} \mathrm{~T}_{2 \mathrm{~g}}(\mathrm{P})$ transitions which tallied with the octahedral symmetry of the complex. The calculated B.M. values of nickel complexes were 1.8, 1.9 and 1.9, which agreed with the distorted octahedral geometry of nickel complexes.

The electronic spectra of $\mathrm{Co}$ (II) complexes showed that $\mathbf{3 b}$ exhibited significant bands at 14467, 21332 and 17384-17565 $\mathrm{cm}^{-1}$, while 4b produced high-energy bands at 14797, 19456 and 21447-21673 $\mathrm{cm}^{-1}$. High energy bands for (5b) were observed at 14782, $21427-21616 \mathrm{~cm}^{-1}$, along with energy band at $19435 \mathrm{~cm}^{-1}$ which were due to ${ }^{4} \mathrm{~T}_{1 \mathrm{~g}}(\mathrm{~F}) \rightarrow{ }^{4} \mathrm{~T}_{2 \mathrm{~g}}(\mathrm{~F})$ and ${ }^{4} \mathrm{~T}_{1 \mathrm{~g}}(\mathrm{~F}) \rightarrow$ ${ }^{4} \mathrm{~T}_{1 \mathrm{~g}}(\mathrm{P})$ transitions for a low-spin octahedral geometry. The calculated B.M. values of cobalt complexes were 1.8 and 1.9 and 1.9 , which agreed with the octahedral geometry of cobalt complexes. The electronic spectra of $\mathrm{Mn}(\mathrm{II})$ complex showed different sharp peaks in the range of $16645,20755,24532$ and $27234 \mathrm{~cm}^{-1}$ for 3c; 18354, 20862, 25568 and $29421 \mathrm{~cm}^{-1}$ for $4 c$, and 18366, 20887, 25589 and $29438 \mathrm{~cm}^{-1}$ for $5 \mathrm{c}$. These peaks were due to ${ }^{4} \mathrm{~T}_{1 \mathrm{~g}}(\mathrm{G}) \rightarrow{ }^{4} \mathrm{~T}_{2 \mathrm{~g}}(\mathrm{G})$, ${ }^{4} \mathrm{~T}_{2 \mathrm{~g}}(\mathrm{G}) \rightarrow{ }^{4} \mathrm{E}_{\mathrm{g}}(\mathrm{G}),{ }^{4} \mathrm{~T}_{1 \mathrm{~g}}(\mathrm{G}) \rightarrow{ }^{4} \mathrm{~A}_{1 \mathrm{~g}},{ }^{4} \mathrm{E}_{\mathrm{g}}(\mathrm{D}) \rightarrow{ }^{4} \mathrm{~T} 1_{\mathrm{g}}(\mathrm{P})$ transitions which are expected in distorted octahedral symmetry of complexes. The calculated B.M. values of manganese complexes were $1.8,2.1$ and 2.1 , which were in agreement with the octahedral geometry of manganese complexes.

\section{Elemental data}

The actual percentage of $\mathrm{C}, \mathrm{H}$ and $\mathrm{N}$ obtained for all the synthesized transition metal (II) complexes of flurbiprofen were compared with the calculated values for their suggested structures. The found and calculated values of all the synthesized flurbiprofen metal (II) complexes are given in Table 2. The found and calculated values were within the acceptable range ( $\pm 0.03-0.95)$, which provided evidence for the formation of the suggested transition metal (II) complexes of flurbiprofen.

\section{Molar conductivity}

Molar conductivities of the synthesized metal complexes were evaluated at room temperature. All the solutions of metal complexes were prepared at a concentration of $\left(1 \times 10^{-3} \mathrm{M}\right)$. It was found that the molar conductivities of the synthesized flurbiprofen metal complexes (3a-3c) were 31,29 and $26 \Omega^{-1} \mathrm{~cm}^{2} \mathrm{~mol}^{-1} 1$, which indicated their non-ionic nature.

However, after adding ethylene-diamine (1, 2diaminoethane) and propane-diamine (1, 3diaminopropane) to these transition metal complexes to form their respective complexes (4a-4c) and tris(1,3-diaminopropane) metal flurbiprofen complexes (5a-c), the conductivities of these metal complexes increased many folds. The conductivities were 186, 174, $163 \Omega^{-}$ ${ }^{1} \mathrm{~cm}^{2} \mathrm{~mol}^{-1}$ for $\mathbf{4 a - 4 c}$, and 175, 169, $153 \Omega^{-}$ ${ }^{1} \mathrm{~cm}^{2} \mathrm{~mol}^{-1}$ for $\mathbf{5 a - 5 c}$. The significant increases in conductivity of the tris-diamine-derived flurbiprofen metal complexes indicate that the complexes were ionic in nature.

\section{Anti-cholinesterase activity}

The anti-cholinesterase activities of all the synthesized complexes were compared as shown in Table 3. Metal complexes derived from 1, 2-diaminoethane (4a-4c) were more potent, with lower $\mathrm{IC}_{50}$ values against both $\mathrm{AChE}$ and BChE, when compared to 1, 3-diaminopropane (5a-5c). Nickel complexes were the most active, and had the least $\mathrm{IC}_{50}$ values, when compared to cobalt and manganese complexes. Among all the synthesized complexes, $4 \mathrm{a}$ produced the most significant inhibitory activities, with $\mathrm{IC}_{50}$ of 2.9 $\pm 0.16 \mu \mathrm{M}$ for $\mathrm{AChE}$, and $\mathrm{IC}_{50}$ of $11.4 \pm 0.58 \mu \mathrm{M}$ for BChE. For 5a, the $I_{50}$ values for $A C h E$ and BChE were $3.80 \pm 0.60$ and $13.30 \pm 1.74 \mu \mathrm{M}$, respectively, when compared to the standard drug galantamine. 
Table 2: Elemental and magnetic susceptibility data

\begin{tabular}{|c|c|c|c|c|c|c|c|c|c|}
\hline Code & $\begin{array}{l}\text { Chemical } \\
\text { formula }\end{array}$ & $\begin{array}{c}\text { Mol. } \\
\text { Weight }\end{array}$ & $\begin{array}{c}\text { Yield } \\
(\%)\end{array}$ & M.pt $\left({ }^{\circ} \mathrm{C}\right)$ & $\begin{array}{c}\%(\mathrm{C}) \\
\text { Found } \\
\text { (Cal) }\end{array}$ & $\begin{array}{c}\%(\mathrm{H}) \\
\text { Found } \\
\text { (Cal) }\end{array}$ & $\begin{array}{c}\%(\mathrm{~N}) \\
\text { Found } \\
\text { (Cal) }\end{array}$ & $\begin{array}{l}\%(M) \\
\text { Found } \\
\text { (Cal) }\end{array}$ & B.M \\
\hline \multirow{2}{*}{$3 a$} & $\mathrm{C}_{30} \mathrm{H}_{28} \mathrm{~F}_{2} \mathrm{O}_{6} \mathrm{Ni}$ & 581.23 & 74 & $165-167$ & 61.99 & 4.86 & --- & 10.10 & \multirow[t]{2}{*}{3.1} \\
\hline & $\mathrm{C}_{36} \mathrm{H}_{50} \mathrm{~F}_{2} \mathrm{~N}_{6} \mathrm{O}_{4} \mathrm{Ni}$ & & & & 61.89 & 4.90 & ---- & 10.13 & \\
\hline \multirow{2}{*}{$4 a$} & & 727.51 & 85 & $282-284$ & 59.43 & 6.93 & 11.55 & 8.07 & \multirow[t]{2}{*}{3.3} \\
\hline & $\mathrm{C}_{39} \mathrm{H}_{54} \mathrm{~F}_{2} \mathrm{~N}_{6} \mathrm{O}_{4} \mathrm{Ni}$ & & & & 59.35 & 6.94 & 11.54 & 8.09 & \\
\hline \multirow{2}{*}{$5 a$} & & 767.56 & 83 & $272-274$ & 61.03 & 7.09 & 10.95 & 7.65 & \multirow[t]{2}{*}{3.3} \\
\hline & & & & & 60.90 & 7.03 & 11.03 & 7.68 & \\
\hline \multirow{2}{*}{$3 b$} & $\mathrm{C}_{30} \mathrm{H}_{28} \mathrm{~F}_{2} \mathrm{O}_{6} \mathrm{Co}$ & 581.47 & 71 & $153-155$ & 61.97 & 4.85 & ---- & 10.14 & \multirow[t]{2}{*}{1.8} \\
\hline & & & & & 61.95 & 4.84 & ---- & 10.14 & \\
\hline \multirow{2}{*}{$4 b$} & $\mathrm{C}_{36} \mathrm{H}_{50} \mathrm{~F}_{2} \mathrm{~N}_{6} \mathrm{O}_{4} \mathrm{Co}$ & 727.75 & 80 & $273-275$ & 59.41 & 6.93 & 11.55 & 8.10 & \multirow[t]{2}{*}{1.8} \\
\hline & & & & & 59.38 & 6.97 & 11.52 & 8.10 & \\
\hline \multirow{2}{*}{$5 b$} & $\mathrm{C}_{39} \mathrm{H}_{54} \mathrm{~F}_{2} \mathrm{~N}_{6} \mathrm{O}_{4} \mathrm{Co}$ & 767.81 & 75 & $265-267$ & 61.01 & 7.09 & 10.95 & 7.68 & \multirow[t]{2}{*}{1.8} \\
\hline & & & & & 60.11 & 7.00 & 10.91 & 7.66 & \\
\hline \multirow{2}{*}{$3 c$} & $\mathrm{C}_{30} \mathrm{H}_{28} \mathrm{~F}_{2} \mathrm{O}_{6} \mathrm{Mn}$ & 577.47 & 77 & $150-152$ & 62.40 & 4.89 & ---- & 9.51 & \multirow[t]{2}{*}{1.9} \\
\hline & & & & & 62.32 & 4.88 & ---- & 9.53 & \\
\hline \multirow{2}{*}{ 4c } & $\mathrm{C}_{36} \mathrm{H}_{50} \mathrm{~F}_{2} \mathrm{~N}_{6} \mathrm{O}_{4} \mathrm{Mn}$ & 723.75 & 76 & $266-268$ & 59.74 & 6.96 & 11.61 & 7.59 & \multirow[t]{2}{*}{2.1} \\
\hline & & & & & 59.69 & 6.97 & 11.63 & 7.54 & \\
\hline \multirow{2}{*}{$5 c$} & $\mathrm{C}_{39} \mathrm{H}_{54} \mathrm{~F}_{2} \mathrm{~N}_{6} \mathrm{O}_{4} \mathrm{Mn}$ & 763.82 & 73 & $257-259$ & 61.33 & 7.13 & 11.00 & 7.19 & \multirow[t]{2}{*}{2.1} \\
\hline & & & & & 61.26 & 7.08 & 11.30 & 7.20 & \\
\hline
\end{tabular}

Table 3: Anti-cholinesterase activities of synthesized tris-diamine metal complexes

\begin{tabular}{llccc}
\hline Code & Compound & \multicolumn{2}{c}{ IC $_{\mathbf{5 0}}(\boldsymbol{\mu M M})^{\mathbf{a}}$} & $\begin{array}{c}\text { Selectivity } \\
\text { index (SI) }\end{array}$ \\
\hline $\mathbf{3 a}$ & $\mathrm{C}_{30} \mathrm{H}_{28} \mathrm{~F}_{2} \mathrm{O}_{6} \mathrm{Ni}$ & $80.3 \pm 1.8$ & $97.5 \pm 2.40$ & 1.2 \\
$\mathbf{4 a}$ & $\mathrm{C}_{36} \mathrm{H}_{50} \mathrm{~F}_{2} \mathrm{~N}_{6} \mathrm{O}_{4} \mathrm{Ni}$ & $\mathbf{2 . 9 \pm 0 . 1 6}$ & $\mathbf{1 1 . 4 \pm 0 . 5 8}$ & 4.5 \\
$\mathbf{5 a}$ & $\mathrm{C}_{39} \mathrm{H}_{54} \mathrm{~F}_{2} \mathrm{~N}_{6} \mathrm{O}_{4} \mathrm{Ni}$ & $\mathbf{3 . 8 \pm 0 . 6 0}$ & $\mathbf{1 3 . 3 \pm 1 . 7 4}$ & 1.9 \\
$\mathbf{3 b}$ & $\mathrm{C}_{30} \mathrm{H}_{28} \mathrm{~F}_{2} \mathrm{O}_{6} \mathrm{Co}$ & $24.4 \pm 0.62$ & $21.0 \pm 0.70$ & 0.8 \\
$\mathbf{4 b}$ & $\mathrm{C}_{36} \mathrm{H}_{50} \mathrm{~F}_{2} \mathrm{~N}_{6} \mathrm{O}_{4} \mathrm{Co}$ & $16.2 \pm 0.13$ & $19.9 \pm 0.44$ & 1.6 \\
$\mathbf{5 b}$ & $\mathrm{C}_{39} \mathrm{H}_{54} \mathrm{~F}_{2} \mathrm{~N}_{6} \mathrm{O}_{4} \mathrm{Co}$ & $20.7 \pm 0.31$ & $13.9 \pm 0.48$ & 0.6 \\
$\mathbf{3 c}$ & $\mathrm{C}_{30} \mathrm{H}_{28} \mathrm{~F}_{2} \mathrm{O}_{6} \mathrm{Mn}$ & $29.4 \pm 0.90$ & $22.1 \pm 0.88$ & 0.7 \\
$\mathbf{4 c}$ & $\mathrm{C}_{36} \mathrm{H}_{50} \mathrm{~F}_{2} \mathrm{~N}_{6} \mathrm{O}_{4} \mathrm{Mn}$ & $17.9 \pm 0.82$ & $16.2 \pm 0.40$ & 0.9 \\
$\mathbf{5 c}$ & $\mathrm{C}_{39} \mathrm{H}_{54} \mathrm{~F}_{2} \mathrm{~N}_{6} \mathrm{O}_{4} \mathrm{Mn}$ & $24.5 \pm 0.70$ & $20.3 \pm 0.52$ & 0.8 \\
$\boldsymbol{A}^{*}$ & $\mathbf{G a l a n t a m i n e}^{\mathbf{a}}$ & $\mathbf{4 . 0 \pm 0 . 1 0}$ & $\mathbf{1 5 . 0 \pm 0 . 6 7}$ & $\mathbf{3 . 7}$ \\
\hline
\end{tabular}

${ }^{a}$ Values are expressed as mean \pm S.E.M. of results from at least three experiments; ${ }^{b} S I=I C_{50}$ ratio (BChE/AChE); $A^{*}=$ Galantamine

\section{DISCUSSION}

In this study, novel tris-diamine-derived transition metal complexes of $\mathrm{Ni}(\mathrm{II}), \mathrm{Co}(\mathrm{II})$ and $\mathrm{Mn}(\mathrm{II})$ were synthesized and characterized by different spectroscopic techniques. X-ray crystallography of $\mathbf{4 a}$ showed that co-ordination sphere around nickel cation was octahedral. The complexes were six-coordinated and surrounded by two flurbiprofen and three ethylene-diamine ligands showing a distorted octahedral environment with a metal center formed by $\mathrm{Ni}, \mathrm{Co}$ and $\mathrm{Mn}$. There were two independent flurbiprofen deprotonated monodentate ligands coordinated to nickel ion via a carboxylate oxygen anions and central tris(1,2 diaminoethane) nickel cation in the crystal structure. Intermolecular and intramolecular hydrogen bonds $(\mathrm{N}-\mathrm{H} \ldots . . \mathrm{O})$ were also present in crystal structure of $4 \mathrm{a}$, which stabilized the molecule. The bond distances were close to those of previously reported nickel complexes with NSAID [20].
FTIR analysis confirmed the chelation between metal and oxygen $\bar{U}(M \leftarrow O)$, and peaks appeared in the range of $451-462 \mathrm{~cm}^{-1}$ for simple flurbiprofen metal complexes, and in the range of 504-594 $\mathrm{cm}^{-1}$ for metal-nitrogen $\bar{U}(M \leftarrow N)$ in diamine-derived metal complexes. Magnetic susceptibility and UV/Vis also suggested distorted octahedral geometry for all the complexes. Conductivity measurements confirmed non-ionic nature of $3 \mathbf{a}-3 \mathbf{e}$, and ionic nature of $4 a-4 e$ and $5 a-5 e$. Results from elemental analysis were also consistent with the proposed structures of the metal complexes.

Metals play important roles in different biological functions, and are important components of many enzymes. The biological roles of metals and their complexes with $\mathrm{Mn}(\mathrm{II}), \mathrm{Co}(\mathrm{II})$, and $\mathrm{Ni}(\mathrm{II})$ are of interest because chelation of metals strongly influence the nature and magnitude of pharmacological activities by interacting with active sites of enzymes [21]. Thus, metal 
chelation is used in many neurobiological and pharmaceutical applications for the treatment of a neurological disease such as $A D[20,22]$. The metal ions in the current study were studied in order to investigate potential synergism or structural interaction with the carboxylic group of flurbiprofen.

It was observed that diverse ligands acted as coligands. The existence of co-ligands is of biological importance because it potentially contributes to enhanced biological activity, and provides novel compounds of structural interest [23]. This is in agreement with the results of the present study in which metal complexes of cobalt, manganese and nickel derived from 1,2diaminoethane (4a-4c), 1,3-diaminopropane (5a5c) and flurbiprofen were found to be more potent, with the least $\mathbf{I C}_{50}$ values against AchE and BChE, when compared to simple metal flurbiprofen complexes. However, nickel complexes possessed higher activity, and had the least $\mathbf{I C}_{50}$ values, when compared to cobalt and manganese. Among the synthesized complexes, $\mathrm{Ni} \quad\left(\mathrm{C}_{2} \mathrm{H}_{8} \mathrm{~N}_{2}\right)_{3} \quad(\mathrm{fp})_{2}$ (4a) and $\mathrm{Ni}$ $\left(\mathrm{C}_{3} \mathrm{H}_{10} \mathrm{~N}_{2}\right)_{3}(\mathrm{fp})_{2}$ (5a) showed significant inhibitory activities against $\mathrm{AChE}$ and $\mathrm{BChE}$, with low $\mathrm{IC}_{50}$ values of $2.9 \pm 0.16,11.4 \pm 0.58$ and $3.8 \pm 0.60$, $13.3 \pm 1.74$, respectively.

The inhibition of AChE by the complexes is similar to the inhibition of $\mathrm{y}$-secretase (gamma secretase), an enzyme responsible for the production of amyloid- $\beta$ peptides $(A \beta)$ involved in $A D$. It has been revealed through computational studies that the number of aliphatic rings, relative number of double bonds and nitrogen atoms connected to heavy atoms with single bonds, are important features for inhibition of gamma secretase for slowing down the pathological progression of $A D$. This is due to electronegative substitution on aryl rings, which increases the value of partial equalization of orbital electronegativities (PEOEs), and substitution of acyclic amines with $\mathrm{N}$-substituted cyclic amines which improves $\mathrm{Y}$-secretase inhibition [24].

Moreover, the superior inhibition in the case of nickel was due to the fact that it has better chelating properties, better bonding to an ionic group, less steric hindrance and more available coordination sites [13]. These results are consistent with findings from studies on metal complexes of nickel and copper with ethylenediamine and glycine, where nickel chelates exerted significant inhibition due to availability of coordination sites in the metal which are more important than chelate charge for the inhibition of AChE [13].

\section{CONCLUSION}

Mixed ligand-derived metal complexes are more active than simple metal flurbiprofen complexes. In addition, nickel complexes are most active in inhibiting $\mathrm{AChE}$ and $\mathrm{BChE}$, with minimal $\mathrm{IC}_{50}$ values relative to cobalt and manganese complexes. The findings also reveal the therapeutic potential of the synthesized complexes as potential drug candidates for the various diseases associated with cholinesterase.

\section{Supplementary materials}

CCDC numbers of 1569831 (4a) corresponded to the supplementary crystallographic data for this paper. These data are available free of charge at http://www.ccdc.cam.ac.uk/conts/retrieving.html

\section{DECLARATIONS}

\section{Acknowledgement}

This work was supported by Department of Chemistry, University of Sargodha, Pakistan.

\section{Conflict of interest}

There is no conflict of interest associated with this work.

\section{Contribution of authors}

The authors declare that work was done by the authors named in this manuscript and all liabilities regarding the content of this article will be borne by them.

\section{REFERENCES}

1. Selkoe, Dennis J. Preventing Alzheimer's Disease. Science 2012, 337(6101): 1488-1492. [DOI: 10.1126/science. 1228541]

2. Johnson E, Brookmeyer $R$, and Ziegler-Graham $K$. Modeling the effect of Alzheimer's disease on mortality. Int J Biostat2007, 3(1): Article 13. [DOI: 10.2202/15574679.1083].

3. Vernino S, Sandroni $P$, Singer W, Low P. Autonomic ganglia Target and novel therapeutic tool. Neurology 2008; 70(20): 1926-1932.

4. Adler $M$, Sweeney $R$, Hamilton $T$, Lockridge O, Duysen E, Purcell A, Deshpande S. Role of acetylcholinesterase on the structure and function of cholinergic synapses: insights gained from studies on knockout mice. Cell MolNeurobiol 2011; 31(6): 909-920.

5. Korabecny J, Musilek K, Holas O, Binder J, Zemek F, Marek J, Kuca K. Synthesis and in vitro evaluation of N- 
alkyl-7-methoxytacrine hydrochlorides as potential cholinesterase inhibitors in Alzheimer disease. Bioorg Med Chem Lett 2010; 20(20): 6093-6095.

6. Yanez M, Vina D. Dual inhibitors of monoamine oxidase and cholinesterase for the treatment of Alzheimer disease. Curr Top Med Chem2013; 13(14): 1692-1706.

7. Kaufman S, Donnell R, Aiken D, Magee C. Prolonged neuromuscular paralysis following rapid-sequence intubation with succinylcholine. Ann Pharmacother 2011; 45(4): 21-29.

8. Folkesson A, Honore $P$, Andersen $L$, Kristensen $P$, Bjerrum O, Low dose of donepezil improves gabapentin analgesia in the rat spared nerve injury model of neuropathic pain: single and multiple dosing studies. J Neural Transm2010; 117(12): 1377-1385.

9. Orhan G, Orhan I, Subutay-Oztekin N, Ak F, Sener B. Contemporary anticholinesterase pharmaceuticals of natural origin and their synthetic analogues for the treatment of Alzheimer's disease. Recent Pat CNS Drug Discov 2009; 4(1): 43-51.

10. Kaduszkiewicz H, Zimmermann T, Beck-Bornholdt $H$, Bussche $H$. Cholinesterase inhibitors for patients with Alzheimer's disease: systematic review of randomised clinical trials. BMJ 2005; 331(7512): 321-327.

11. Pakaski M, Kasa P. Role of acetylcholinesterase inhibitors in the metabolism of amyloid precursor protein. Curr Drug Targets CNS NeurolDisord 2003; 2(3): 163-171.

12. Al-Jafari A. The inhibitory effect of tetramethylethylene diamine on water soluble and membrane bound acetylcholinesterase activity. Int $J$ Biochem 1993; 25(3): 319-24.

13. Bolton S. Inhibition of Acetylcholinesterase by Chelates II. J Pharm Sci 1965; 54(4): 583-586.

14. Liang $K$, Lin $Y$, Leron R, Li M. Molar heat capacity of aqueous solutions of 1,3-diaminopropane and 1,4diaminobutane and their piperazine blends. Thermochim Acta 2015;616: 42-48

15. Ali M, Yar M, Hasan M, Ahsan M, Pandian S. Design, synthesis and evaluation of novel 5, 6-dimethoxy-1-oxo-
2, 3-dihydro-1H-2-indenyl-3, 4-substituted phenyl methanone analogues. Bioorg Med Chem Lett2009; 19(17): 5075-5077.

16. Sarfraz M, Sultana N, Rashid U, Akram MS, Sadiq A, Tariq MI. Synthesis, biological evaluation and docking studies of 2, 3-dihydroquinazolin-4 (1H)-one derivatives as inhibitors of cholinesterases. Bioorg Chem 2017; 70: 237-244.

17. Scheldrick GM. A short history of SHELX. Acta CrystA 2008; 64(1): 112-122.

18. Siemens S, Saint $M$, Area-Detector Control and Integration Software. Siemens Analytical X-ray Instruments IncMadison WI, USA 1995.

19. Ellman GL, Courtney KD, Andres Jr. V, Featherstone RM. A new and rapid colorimetric determination of acetylcholinesterase activity. Biochem Pharmacol 1961; 7(2): 88-95

20. Totta X, Papadopoulou, A, Hatzidimitriou A, Papadopoulos A, Psomas G. Synthesis, structure and biological activity of nickel complexes with mefnamato and nitrogen donor ligands. J Inorg Biochem 2015; 145 : 79-93.

21. Bonda D, Lee H, Blair J, Zhu X, Perry G, Smith M. Role of metal dyshomeostasis in Alzheimer disease. Metallomics2011;3(3): 267-270.

22. Kopel P, Dolezal, K, Langer V, Jun D, Adam V, Kuca K, Kizek R. Trithiocyanurate Complexes of Iron, Manganese and Nickel and Their Anticholinesterase activity. Molecules 2014; 19: 4338-4354.

23. Psomas G, Kessissoglou D. P. Quinolones and nonsteroidal anti-inflammatory drugs interacting with copper(II), nickel(II), cobalt(II) and zinc(II): Structural features, biological evaluation and perspectives. Dalton Trans 2013; 42(18): 6252-6276.

24. Manoharan P, Ghoshal N. In: Computational Modeling of Gamma-Secretase Inhibitors as Anti-Alzheimer Agents, Ed: by Roy K. Computational Modeling of Drugs Against Alzheimer's Disease. Neuromethods Vol. 132, Humana Press, New York, NY. 2018, pp 283-303. [DOI:10.1007/978-1-4939-7404-7_12]. 